\title{
CHANGES IN THE TERRITORIAL ORGANIZATION OF THE "VOLGA-AKHTUBA FLOODPLAIN" NATURAL PARK WITH AN INCREASE IN ANTHROPOGENIC LOAD IN THE PERIOD FROM THE BEGINNING OF THE 2000s TO 2020
}

\author{
Sergey A. Istomin \\ Russian Information, Analytical and Scientific Research Water Management Center, \\ Rostov-on-Don, Russian Federation; \\ Volgograd State University, Volgograd, Russian Federation
}

Anna V. Kholodenko

Volgograd State University, Volgograd, Russian Federation

\begin{abstract}
The territory of the Volga-Akhtuba floodplain within Volgograd region, included in the natural park Volga-Akhtuba floodplain, has been subjected to anthropogenic impact for many years. Initially, in order to regulate economic activities, the natural park space was divided into three functional zones: environmental, recreational, and agricultural. In subsequent years, within the natural park Volga-Akhtuba floodplain, due to the increased anthropogenic load on the landscapes, it became necessary to adjust the spatial organization of areas with different purposes. In the actual version of functional zoning, five functional zones (agrarian landscapes, environmental, recreational, extensive nature management and buffer) are presented. In order to determine the transformation of the natural park Volga-Akhtuba floodplain spatial organization, changes in the functional zoning of this specially protected natural area during the period from the beginning of the 2000s to 2020 were revealed with the use of geoinformation systems. Most of the lands have not changed their legal status. The agricultural zone underwent the main transformation, most of which were transferred to the recreational zone. The territory of environmental zone that includes the most valuable natural complexes and objects has been squeezed out to territories that are less profitable for nature users. The lands of the Sredneakhtubinsky district are most exposed to anthropogenic impact, since this municipality includes significant areas occupied $\widehat{\delta}$ by zones of extensive nature management and agrarian landscapes, within which the most destructive nature management for ecosystems is carried out, while the ratio of nature protection spaces to the area of the municipality is the smallest. In the Svetloyarsk district, the ecological situation is the most favorable, since almost the entire territory is occupied by an environmental functional zone.
\end{abstract}

Key words: Volga-Akhtuba floodplain, natural park, functional zoning, change in territorial organization, anthropogenic load.

Citation. Istomin S.A., Kholodenko A.V. Changes in the Territorial Organization of the "Volga-Akhtuba Floodplain" Natural Park with an Increase in Anthropogenic Load in the Period from the Beginning of the 2000s to 2020. Prirodnye sistemy i resursy [Natural Systems and Resources], 2021, vol. 11, no. 3, pp. 26-33. DOI: https://doi.org/10.15688/nsr.jvolsu.2021.3.4 


\title{
ИЗМЕНЕНИЕ ТЕРРИТОРИАЛЬНОЙ ОРГАНИЗАЦИИ ПРИРОДНОГО ПАРКА «ВОЛГО-АХТУБИНСКАЯ ПОЙМА» С РОСТОМ АНТРОПОГЕННОЙ НАГРУЗКИ В ПЕРИОД С НАЧАЛА 2000-х ГОДОВ ДО 2020 ГОДА
}

\author{
Сергей Александрович Истомин \\ Российский информационно-аналитический и научно-исследовательский водохозяйственный центр, \\ г. Ростов-на-Дону, Российская Федерация; \\ Волгоградский государственный университет, г. Волгоград, Российская Федерация
}

Анна Викторовна Холоденко

Волгоградский государственный университет, г. Волгоград, Российская Федерация

\begin{abstract}
Аннотация. Территория Волго-Ахтубинской поймы в границах Волгоградской области, выведенная в состав природного парка «Волго-Ахтубинская пойма», многие годы подвергается антропогенному воздействию. Изначально пространство природного парка с целью регулирования хозяйственной деятельности было разделено на три функциональные зоны: природоохранная; рекреационная; агрохозяйственная. В последующие годы в пределах природного парка «Волго-Ахтубинская пойма» в связи с возросшей антропогенной нагрузкой на ландшафты возникла необходимость корректировки пространственной организации участков с различным назначением. В актуальном варианте функционального зонирования представлено пять функциональных зон: агроландшафтов; природоохранная; рекреационная; экстенсивного природопользования и буферная. С целью определения преобразования пространственной организации природного парка «Волго-Ахтубинская пойма» при помощи геоинформационных систем выявлены изменения функционального зонирования данной особо охраняемой природной территории в период с начала 2000-х годов по 2020 год. Большая часть земель не изменили своего правового статуса. Основной трансформации подверглась агрохозяйственная зона, большая часть которой была переведена в рекреационную. Природоохранная зона, на территории которой находятся наиболее ценные природные комплексы и объекты, вытеснена на менее выгодные для природопользователей территории. Земли Среднеахтубинского муниципального района в наибольшей степени подвержены антропогенному воздействию, так как в пределах данного муниципалитета значительные пространства занимают зоны экстенсивного природопользования и агроландшафтов, в пределах которых осуществляется наиболее разрушительное для экосистем природопользование, тогда как отношение природоохранных пространств к площади муниципалитета наименьшее. В Светлоярском районе экологическая ситуация наиболее благоприятная, так как практически всю территорию занимает природоохранная функциональная зона.
\end{abstract}

Ключевые слова: Волго-Ахтубинская пойма, природный парк, функциональное зонирование, изменение территориальной организации, антропогенная нагрузка.

Цитирование. Истомин С. А., Холоденко А. В. Изменение территориальной организации природного парка «Волго-Ахтубинская пойма» с ростом антропогенной нагрузки в период с начала 2000-х годов до 2020 года //Природные системы и ресурсы. - 2021. - Т. 11, № 3. - C. 26-33. -DOI: https://doi.org/10.15688/nsr.jvolsu.2021.3.4

\section{Введение}

На севере города-героя Волгограда от реки Волга отделяется рукав Ахтуба, образуя в своем междуречье уникальную интразональную территорию Волго-Ахтубинской поймы, которая играет важную роль в сохранении биологического разнообразия всей Нижней Волги.
Ландшафты поймы долгие годы использовались в интересах хозяйства, однако местами данная территория сохранила слабоизмененные и неизмененные экосистемы $[1 ; 6]$. В 2000 г. в северной части Волго-Ахтубинской поймы в пределах Волгоградской области был создан одноименный природный парк [3]. При создании природного парка планировалось достижение гармонии в эколого- 


\section{РЕСУ РСОВЕДЕНИЕ}

хозяйственном балансе территории Волго-Ахтубинской поймы. Организация хозяйственной деятельности должна вестись с учетом обеспечения устойчивого развития природы и общества, однако в настоящее время территория поймы подвергается значительному антропогенному воздействию.

\section{Материалы и методы}

Изначально территория природного парка с целью регулирования хозяйственной деятельности была разделена на три функциональные зоны: природоохранная, рекреационная, агрохозяйственная [2].

В результате привязки изображения функционального зонирования природного парка «Волго-Ахтубинская пойма» к космическому снимку Landsat-8 от 02.07.2020 г. проведена векторизация изображения в системе координат проекта (WGS 84 / UTM zone $38 \mathrm{~N})$. В итоге была создана картосхема «Функциональное зонирование природного парка "Волго-Ахтубинская пойма" по состоянию на начало 2000-х годов» (рис. 1, $a$ ) [4].

Согласно расчетам, проведенным по данной картосхеме (см. рис. 1, a), было выявлено, что наибольшую площадь занимает зона рекреационного использования, которая располагается в основном на территории Ленин- ского муниципального района и составляет $65 \%$ от всей площади этой функциональной зоны. Значительно меньшие территории данная зона занимает в границах Среднеахтубинского и Светлоярского муниципальных районов, $31 \%$ и $4 \%$ соответственно.

Большая часть агрохозяйственной зоны природного парка «Волго-Ахтубинская пойма» находится в границах Среднеахтубинского муниципального района Волгоградской области, а именно $81 \%$. Меньшие площади данная функциональная зона занимает в Ленинском муниципальном районе. На территории Светлоярского муниципального района агрохозяйственная зона не представлена.

Природоохранная зона, направленная на сохранение естественных ландшафтов в сочетании с реализацией экологического туризма, представлена во всех муниципальных районах, чья территория включена в состав природного парка. Основные участки рекреационного назначения располагаются в границах Ленинского муниципального района и занимают $55 \%$ площади данной функциональной зоны. Меньшие территории в природоохранной зоне представлены в Светлоярском и Среднеахтубинском муниципальных районах (26\% и $19 \%$ соответственно). Стоит отметить, что эта зона занимает 84 \% части Светлоярского

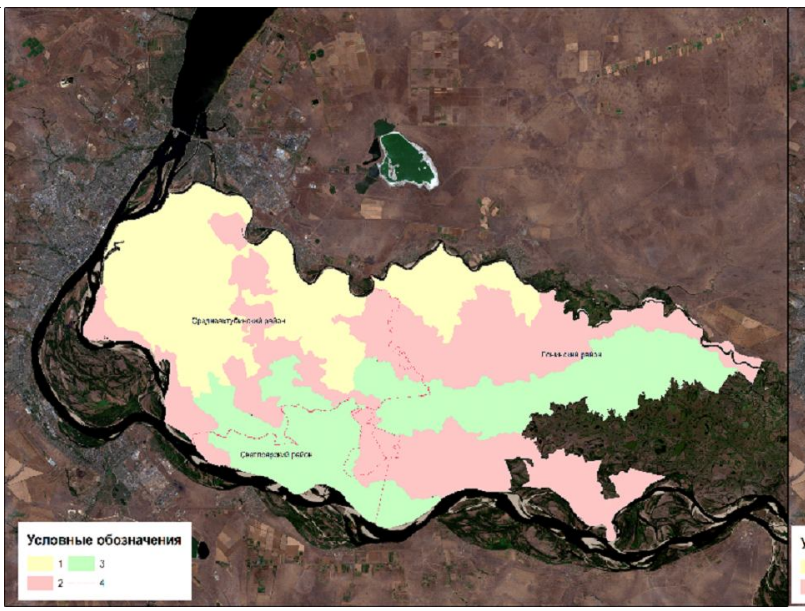

$a$

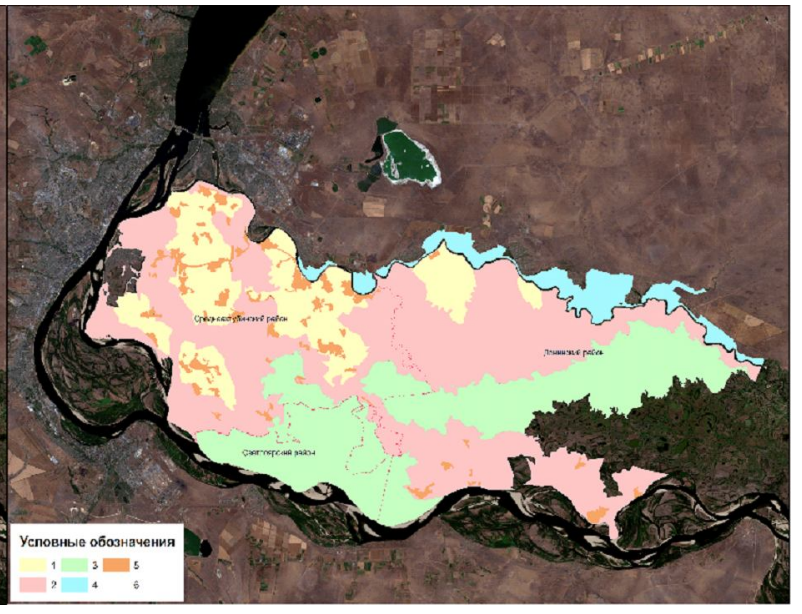

$\sigma$

Рис. 1. Функциональное зонирование природного парка «Волго-Ахтубинская пойма» $[1 ; 2 ; 5]$ : $a$ - по состоянию на начало 2000-х гг. (1 - агрохозяйственная зона; 2 - зона рекреационного использования; 3 - природоохранная зона; 4 - граница муниципальных образований);

$\sigma$ - по состоянию на 2020 г. ( 1 - зона агроландшафтов; 2 - зона рекреационного использования; 3 - природоохранная зона; 4 - буферная зона; 5 - экстенсивного природопользования; 6 - граница муниципальных образований) 
муниципального района, которая также входит в состав природного парка.

В последующие годы на территории природного парка «Волго-Ахтубинская пойма» в связи с возросшей антропогенной нагрузкой на ландшафты возникла необходимость корректировки пространственной организации участков с различным назначением. Результаты были закреплены постановлением Администрации Волгоградской области от 22.06.2016 г. № 389-п «Об утверждении положения о природном парке “Волго-Ахтубинская пойма"» в части о новом функциональном зонировании его территории. В новом варианте представлено пять функциональных зон: агроландшафтов; природоохранная; рекреационная; экстенсивного природопользования и буферная [3; 5].

В результате привязки изображения «СХема границ функциональных зон природного парка “Волго-Ахтубинская пойма"», взятого из постановления Администрации Волгоградской области от 22.06.2016 года № 389-п «Об утверждении положения о природном парке “Волго-Ахтубинская пойма"), к космическому снимку Landsat-8 от 02.07.2020 г. [7] проведена векторизация изображения в системе координат проекта (WGS 84 / UTM zone 38N). Итогом стала картосхема «Функциональное зонирование природного парка "Волго-Ахтубинская пойма" по состоянию на 2020 год» (см. рис. 1, б) [3].

При проведенном анализе данной картосхемы (см. рис. 1, б) можно сделать вывод, что основную площадь занимает зона рекреационного использования, большая часть которой располагается в Ленинском муниципальном районе и составляет $56 \%$ от общей площади данной зоны. Меньшие площади (42 \%) эта зона занимает в границах Среднеахтубинского муниципального района. Значительно меньшие территории зона рекреационного использования занимает в Светлоярском муниципальном районе (всего 2 \%).

Зона агроландшафтов располагается в основном в Среднеахтубинском муниципальном районе и составляет 83 \% от площади данной функциональной зоны. Остальная часть этой зоны располагается в Ленинском муниципальном районе.

Буферная зона находится на левом берегу реки Ахтуба, в основном в Ленинском му- ниципальном районе, и составляет 89 \% от его общей площади, остальные $11 \%$ приходятся на Среднеахтубинский муниципальный район.

Основная часть зоны экстенсивного природопользования (и, как следствие, основное количество селитебных территорий) располагается в границах Среднеахтубинского муниципального района и составляет 86 \% от площади данной функциональной зоны, остальные 14 \% приходятся на Ленинский муниципальный район.

Наиболее ценные экосистемы природного парка располагаются на территории природоохранной функциональной зоны и составляют $57 \%$ от ее площади, их основная часть относится к Ленинскому муниципальному району. Меньшие площади данная функциональная зона занимает на территории Светлоярского и Среднеахтубинского муниципальных районов и составляет соответственно $31 \%$ и $12 \%$. Стоит отметить, что в Светлоярском муниципальном районе данная зона занимает 94\%. Таким образом, на территории Светлоярского муниципального района отсутствуют участки парка, подверженные интенсивной антропогенной нагрузке.

Для выявления изменений в пространственных и площадных характеристиках зонирования природного парка «Волго-Ахтубинская пойма» в программе ArcGIS из векторных слоев картосхем «Функциональное зонирование природного парка “Волго-Ахтубинская пойма" на начало 2000-х гг.» и «Функциональное зонирование природного парка "Волго-Ахтубинская пойма" по состоянию на 2020 г.» были выявлены основные изменения в территориальной организации данной региональной ООПТ. По результатам получены данные об изменении площадей отдельных функциональных зон природного парка (см. табл. 1).

Большая часть участков природного парка не изменили своего функционального назначения и подхода к природопользованию и регламентированию антропогенной нагрузки. Наиболее сильному изменению подверглись территории агрохозяйственной функциональной зоны. В частности, большая часть земель переведена в зону рекреационного использования, 71 \% таких земель - в Среднеахтубинском муниципальном районе и 29 \% - в Ленинском. В зону экстенсивного природополь- 
зования переведены значительные площади агрохозяйственной функциональной зоны, 98 \% таких земель - в Среднеахтубинском муниципальном районе. Также часть агрохозяйственной зоны в Среднеахтубинском муниципальном районе была выведена из состава природного парка.

Зона рекреационного использования по версии на начало 2000-х гг. подверглась незначительному изменению в территориальном зонировании по состоянию на 2020 год. Большая часть измененных территорий переведена в природоохранную функциональную зону, 59 \% таких земель - в Ленинском муниципальном районе, $31 \%$ - в Светлоярском и $10 \%$ в Среднеахтубинском. Значительные площади природного парка переведены в зону экстенсивного природопользования, причем $63 \%$ из них - в Ленинском муниципальном районе, $37 \%$ - в Среднеахтубинском. Часть природного парка, расположенная в начале 2000-х на левом берегу реки Ахтуба, переведена в буферную функциональную зону. Незначительные территории переведены из зоны рекреационного использования в зону агроландшафтов в Ленинском и Среднеахтубинском муниципальных районах.
Основная часть наиболее ценных участков природного парка «Волго-Ахтубинская пойма», которые отнесены к природоохранной функциональной зоне, в основном не изменили своего правового статуса. Так, часть природоохранных территорий переведена в земли рекреационного использования, $60 \%$ таких земель - в Среднеахтубинском, и $40 \%$ - в Ленинских муниципальных районах. Незначительная часть выведена из природоохранной зоны в зоны агроландшафтов и экстенсивного природопользования, в основном на территории Среднеахтубинского муниципального района Волгоградской области.

В состав природного парка дополнительно были включены территории на левом берегу реки Ахтуба, которые получили статус буферной зоны, созданной с целью сохранения ландшафтно-экологической целостности экосистем природного парка, а также для снижения влияния антропогенных факторов на уникальные экосистемы поймы.

В результате анализа изменения статуса отдельных участков природного парка было выявлено, что наименьшим изменениям подверглись территории Светлоярского муниципального района, в котором природо-

Таблица 1

Изменение функциональных зон природного парка «Волго-Ахтубинская пойма» с начала 2000-х гг. по 2020 г.

\begin{tabular}{|c|c|c|c|}
\hline $\begin{array}{c}\text { Функциональная зона } \\
\text { в начале } 2000-x \text { гг. }\end{array}$ & $\begin{array}{c}\text { Площадь } \\
\text { в начале } 2000-\text { х гг., км } \\
\end{array}$ & $\begin{array}{c}\text { Функциональная зона } \\
\text { в } 2020 \text { г. }\end{array}$ & $\begin{array}{c}\text { Площадь } \\
\text { в } 2020 \text { г., км } \\
\end{array}$ \\
\hline \multirow{4}{*}{ Агрохозяйственная зона } & \multirow{4}{*}{443,61} & Агроландшафтов & 227,96 \\
\hline & & $\begin{array}{l}\text { Рекреационного } \\
\text { использования }\end{array}$ & 147,40 \\
\hline & & $\begin{array}{l}\text { Экстенсивного } \\
\text { природопользования }\end{array}$ & 47,29 \\
\hline & & $\begin{array}{l}\text { Вышедшие из состава } \\
\text { природного парка }\end{array}$ & 20,96 \\
\hline \multirow{5}{*}{$\begin{array}{l}\text { Зона рекреационного } \\
\text { использования }\end{array}$} & \multirow{5}{*}{568,93} & $\begin{array}{l}\text { Рекреационного } \\
\text { использования }\end{array}$ & 503,92 \\
\hline & & Агроландшафтов & 3,02 \\
\hline & & $\begin{array}{l}\text { Экстенсивного } \\
\text { природопользования }\end{array}$ & 12,20 \\
\hline & & Буферная зона & 5,48 \\
\hline & & Природоохранная зона & 44,31 \\
\hline \multirow{4}{*}{ Природоохранная зона } & \multirow{4}{*}{428,2} & Природоохранная зона & 380,65 \\
\hline & & $\begin{array}{l}\text { Экстенсивного } \\
\text { природопользования }\end{array}$ & 1,17 \\
\hline & & $\begin{array}{l}\text { Рекреационного } \\
\text { использования }\end{array}$ & 39,98 \\
\hline & & Агроландшафтов & 6,40 \\
\hline $\begin{array}{l}\text { Территории, не входящие } \\
\text { в состав природного парка }\end{array}$ & 76,87 & Буферная зона & 76,87 \\
\hline
\end{tabular}


охранная зона приобрела еще большее значение. Данный факт свидетельствует о высокой значимости данной территории в сохранении биологического разнообразия Нижней Волги.

В Ленинском муниципальном районеучастки парка в основном не изменили своего правового статуса, основными изменениями можно считать вывод значительной части агрохозяйственной зоны в зону рекреационного использования. Также часть природоохранных территорий вошли в состав зоны рекреационного использования, а часть территорий рекреации, наоборот, были переведены в природоохранную зону.

В Среднеахтубинском муниципальном районе произошли заметные изменения в распределении участков по функциональному назначению. Основные изменения касаются вывода из агрохозяйственной зоны значительной части территории в зону рекреационного и экстенсивного природопользования. Также стоит отметить, что из природоохранной зоны были выведены участки в другие функциональные зоны природного парка, а обратно были включены незначительные площади из зоны рекреации.

В настоящее время по сравнению с началом 2000-х функциональные зоны природного парка «Волго-Ахтубинская пойма» имеют следующие площади (табл. 2).

\section{Заключение}

Территориальное зонирование природного парка претерпело значительные изменения (см. табл. 1, 2). Агрохозяйственная зона сократилась на 46,49 \%, зона рекреационного использования увеличилась на $21,51 \%$, а природоохранная зона сократилась в целом на 0,76 \%. В границах природного парка были вве- дены буферная зона и зона экстенсивного природопользования.

По результатам исследований можно сделать вывод о том, что северная часть Волго-Ахтубинской поймы играет значимую роль как в сохранении биологического разнообразия, так и в развитии экономики Волгоградской области. С учетом пространственного сочетания конфликтных видов природопользования на данной территории особое внимание необходимо уделять эффективности внутреннего устройства природного парка «Волго-Ахтубинская пойма». Особенно с учетом активного развития рекреационной и сельскохозяйственной деятельности, а также развития селитебных зон.

В составе парка находятся два крупных природоохранных кластера, расположенных в основном в Ленинском и Светлоярском муниципальных районах, на которых располагаются наименее измененные природные комплексы и объекты. В результате изменения границы природоохранной зоны эти объекты были вытеснены активной хозяйственной деятельностью на менее выгодные для природопользователей территории, что подтверждает приоритетность экономических интересов относительно задач поддержания устойчивости ценных в природоохранном плане экосистем регионального уровня.

Среднеахтубинский муниципальный район в наибольшей степени подвергнут антропогенному воздействию, так как в его территориальном составе значительную роль играют зоны экстенсивного природопользования, оказывающие значительное влияние на экологическое состояние поймы и зоны агроландшафтов, а также для территории данного района наблюдается наименьшее отношение площади природоохранной зоны к площади муниципального района.

Таблииа 2

Изменение площадей функциональных зон природного парка «Волго-Ахтубинская пойма» с начала 2000-х гг. по 2020 г.

\begin{tabular}{|c|c|c|c|c|}
\hline $\begin{array}{c}\text { Функциональная зона } \\
\text { (начало 2000-х гг.) }\end{array}$ & $\begin{array}{c}\text { Площадь (начало } \\
\text { 2000-х гг.), км }\end{array}$ & $\begin{array}{c}\text { Функциональная зона } \\
(2020 \text { г.) }\end{array}$ & $\begin{array}{c}\text { Площадь } \\
(2020 \text { г. }), \text { км }^{2} \\
\end{array}$ & $\begin{array}{c}\text { Изменение } \\
\text { площади, \% }\end{array}$ \\
\hline Агрохозяйственная зона & 443,61 & Агроландшафтов & 237,38 & 53,51 \\
\hline $\begin{array}{l}\text { Зона рекреационного } \\
\text { использования }\end{array}$ & 568,93 & $\begin{array}{l}\text { Зона рекреационного } \\
\text { использования }\end{array}$ & 691,30 & 121,51 \\
\hline Природоохранная зона & 428,20 & Природоохранная зона & 424,96 & 99,24 \\
\hline Буферная зона & 0,00 & Буферная зона & 82,35 & - \\
\hline $\begin{array}{l}\text { Экстенсивного } \\
\text { природопользования }\end{array}$ & 0,00 & $\begin{array}{l}\text { Экстенсивного } \\
\text { природопользования }\end{array}$ & 60,66 & - \\
\hline
\end{tabular}




\section{РЕСУ РСОВЕДЕНИЕ}

\section{СПИСОК ЛИТЕРАТУРЫ}

1. Дистанционные исследования и картографирование состояния антропогенно-трансформированных территорий юга России / В. В. Новочадов, А. С. Рулев, В. Г. Юферев, Е. А. Иванцова // Известия Нижневолжского агроуниверситетского комплекса: наука и высшее профессиональное образование. - 2019. - Т. 1, № 53. - С. 151-158.

2. Об утверждении Положения о государственном учреждении «Природный парк "Волго-Ахтубинская пойма”» : приказ Комитета охраны природы Администрации Волгоградской области № 54/01 : (утв. 14 февраля 2007 г.) // Информационно-правовой портал «Гарант.ру». - Электрон. текстовые дан. Режим доступа: http://base.garant.ru/20130257/ (дата обращения: 19.02.2021). - Загл. с экрана.

3. Об утверждении Положения о природном парке «Волго-Ахтубинская пойма» : постановление Администрации Волгоградской области № 389-п : (утверждено 22 июля 2016 года) : (с изм. и доп.) // Электронный фонд правовой и нормативно-правовой документации. - Электрон. текстовые дан. - Режим доступа: http://docs.cntd.ru/document/441604043/ (дата обращения: 19.02.2021). - Загл. с экрана.

4. О создании государственного учреждения «Природный парк “Волго-Ахтубинская пойма"» : постановление Главы Администрации Волгоградской области № 404 : (утв. 05 июня 2000 г.) // Электронный фонд правовой и нормативно-правовой документации. - Электрон. текстовые дан. - Режим доступа: http://docs.cntd.ru/document/430658848/ (дата обращения :19.02.2021). - Загл. с экрана.

5. Отчет о научно-исследовательской работе «Материалы комплексного экологического обследования территории природного парка, в части изменения режимно-функционального зонирования» : по Договору № 01/08.16 от 01.08.2016 г. - 286 с.

6. Ряснов, В. А. Применение метода дешифрирования космоснимков при оценке состояния лесных ценозов Волго-Ахтубинской поймы / В. А. Ряснов, Е. А. Иванцова // Экологическая безопасность и охрана окружающей среды в регионах России: теория и практика : материалы Всерос. науч.-практ. конф. - Волгоград, 2015. - С. 204-209.

7. U.S. Geological Survey// USGS Science for a Changing World. - Electronic text data. - Mode of access: https://earthexplorer.usgs.gov/ (date of access: 19.02.2021). - Title from screen.

\section{REFERENCES}

1. Novochadov V.V., Rulev A.S., Yuferev V.G., Ivantsova E.A. Distanzionnye issledovanija i kartografirovanie sostojanija antropogenno- transformirovannyh territorij yuga Rossii [Remote Research and Mapping the State of AnthropogenicTransformed Territories of the South of Russia]. Izvestiya Nizhnevolzhskogo agrouniversitetskogo kompleksa: Nauka i vysshee professionalnoe obrazovanie, 2019, vol. 1, no. 53, pp. 151-158.

2. $\mathrm{Ob}$ utverzhdenii Polozheniya o gosudarstvennom uchrezhdenii «Prirodnyi park "VolgoAkhtubinskhaya poima"»: prikaz Komiteta ohrany prirody Administratsii Volgogradskoi oblasti № 54/01: (utv. 14 fevralya 2007 g.) [On the Approval of the Regulations on the State Institution "Natural Park "VolgaAkhtuba Floodplain"”: Order of the Nature Protection Committee of the Administration of the Volgograd Region No. 54/01 (Approved on February 14, 2007)]. Informatsionno-pravovoi portal "Garant.ru» [Information and Legal Portal "Garant.ru”]. URL: http:// base.garant.ru/20130257/ (accessed 19 February 2021).

3. Ob utverzhdenii Polozheniya o prirodnom parke «Volgo-Akhtubinskhaya poima»: postanovlenie Administratsii Volgogradskoi oblasti № 389-p: (utverzhdeno 22 iyulya 2016 goda): (s izm. i dop.) [On Approval of the Regulations on the Natural Park Volga-Akhtuba Floodplain: Resolution of the Volgograd Region Administration No. 389-p (Approved on July 22, 2016): (As Amended and Supplemented)]. Elektronnyi fond pravovoi i normativno-pravovoi dokumentatsii [Electronic Fund of Legal and Regulatory Documents]. URL: http://docs.cntd.ru/document/441604043 (accessed 19 February 2021).

4. O sozdanii gosudarstvennogo uchrezhdeniya «Prirodnyi park "Volgo-Akhtubinskhaya poima"»: postanovlenie Glavy Administratsii Volgogradskoi oblasti № 404: (utv. 05 iiunia 2000 g.) [On the Establishment of the State Institution "Natural Park "Volga-Akhtuba Floodplain": Resolution of the Head of the Volgograd Region Administration No. 404 (Approved on June 5, 2000)]. Elektronnyi fond pravovoi $i$ normativno-pravovoi dokumentatsii [Electronic Fund of Legal and Regulatory Documents]. URL: http://docs.cntd.ru/document/430658848/ (accessed 19 February 2021).

5. Otchet o nauchno-issledovatelskoi rabote "Materialy kompleksnogo ekologicheskogo obsledovaniia territorii prirodnogo parka, v chasti izmeneniya rezhimno-funktsionalnogo zonirovaniya»: po Dogovoru № 01/08.16 ot 01.08.2016 g. [Report on Research Work "Materials of a Comprehensive Environmental Survey of the Territory of a Natural Park in Terms of Changing the Regime and Functional Zoning", Under the Contract No. 01/08.16 Dated August 1, 2016]. 286 p.

6. Rjasnov V.A., Ivantsova E.A. Primenenie metoda deshifrirovaniya kosmosnimkov pri otsenke sostoyaniya lesnykh tsenozov Volgo-Achtybinskoi poimy [Applications of the Method of Decoding 
Satellite Images in Assessing the State of Forest Cenoses of the Volga-Akhtuba Floodplain]. Ekologicheskaya bezopasnost $i$ okhrana okruzhayushchei sredy v regionakh Rossii: teoriya $i$ praktika: materialy Vseros. nauch.-prakt. konf. [Ecological Safety and Environmental Protection in
Russian Regions: Theory and Practice. Proceedings of the All-Russian Scientific and Practical Conference], 2015, pp. 204-209.

7. U.S. Geological Survey. USGS Science for a Changing World. URL: https://earthexplorer.usgs.gov (accessed 19 February 2021).

\section{Information About the Authors}

Sergey A. Istomin, Leading Engineer, Russian Information, Analytical and Scientific Research Water Management Center, Maksima Gorkogo St, 239, 344022 Rostov-on-Don, Russian Federation; Master Student, Volgograd State University, Prosp. Universitetsky, 100, 400062 Volgograd, Russian Federation, sergej.ist@yandex.ru

Anna V. Kholodenko, Candidate of Sciences (Geography), Associate Professor, Department of Ecology and Nature Management, Volgograd State University, Prosp. Universitetsky, 100, 400062 Volgograd, Russian Federation, kholodenko@volsu.ru

\section{Информация об авторах}

Сергей Александрович Истомин, ведущий инженер, Российский информационно-аналитический и научно-исследовательский водохозяйственный центр, ул. Максима Горького, 239, 344022 г. Ростов-на-Дону, Российская Федерация; магистрант, Волгоградский государственный университет, просп. Университетский, 100, 400062 г. Волгоград, Российская Федерация, sergej.ist@yandex.ru

Анна Викторовна Холоденко, кандидат географических наук, доцент кафедры экологии и природопользования, Волгоградский государственный университет, просп. Университетский, 100, 400062 г. Волгоград, Российская Федерация, kholodenko@volsu.ru 